\title{
NUMERICAL-EXPERIMENTAL ANALYSIS OF THE FOLDABLE CONTAINERS STRENGTH
}

\author{
Sevket Čelović, Miloš Tipsarević, Taško Maneski, Tomaž, Vuherer, Dražan Kozak
}

Original scientific paper

This paper describes the numerical and the experimental methodology for analysis of plastic packaging strength characteristics that are representative of its strength in the real life. Numerical analysis was conducted by the application of finite elements using "KOMIPS" software. The experiments were executed with the equipment "GOM" and software application "ARAMIS". The main issues we want to answer are related to correctly ordering and defining characteristics of container. This article will show how we can predict experimental results by the means of finite element analysis; we find this is a very strong learning tool that would enable designers to improve the structural strength of new products in the future. Experimental and numerical analysis results have to date shown a high degree of correlation.

Keywords: experiment; FEM; foldable container; strength

Numeričko-eksperimentalno određivanje čvrstoće rasklopivih kontejnera

Izvorni znanstveni članak

Ovaj rad opisuje numeričku i eksperimentalni metodologiju za analizu karakteristika čvrstoće plastične ambalaže koja iskazuju svoju izdržljivost u realnoj eksploataciji. Numerička analiza je provedena primjenom konačnih elemenata uporabom "KOMIPS" softvera. Eksperimenti su izvedeni s opremom "GOM" i softverskom aplikacijom "ARAMIS". Osnovna pitanja na koje želimo odgovoriti su vezana za korektno određivanje i definiranje karakteristike kontejnera. Ovaj rad će pokazati kako se može predvidjeti eksperimentalne rezultate pomoću metode konačnih elemenata; držimo da je to vrlo važan alat za učenje koje omogućava dizajnerima da poboljšaju čvrstoću strukture novih proizvoda u budućnosti. Numerički i eksperimentalni rezultati analize do sada su pokazali visok stupanj korelacije.

Ključne riječi: eksperiment; FEM; čvrstoća; rasklopivi kontejner

\section{Introduction}

The paper deals with complex geometry of the considered foldable containers and influence of geometry on the strength of the container. Different models were developed to describe the structure of foldable container. We used numerical analysis which implies application of the finite element methodology. Experimental analysis included measurement of deformation by utilisation of optical digital cameras (GOM, Germany). The objective was to verify the calculation model and precise detection of the strength of the container.

The strength of a container is defined by its deformation, stiffness and parameters that categorize the container.

Containers are made up of the following components: base, two short and two long side walls. Each side latches onto the base via hinges. Between two adjacent sides there are latches that allow firm connection when container is upright. Each side wall consists of: base area, latches, hinges and vertical side contact area. The most important elements of the container are: the base, sides and connections between them (hinges and latches).

The main problem of diagnosing the behaviour of the container is the inability to consistently model the connections between elements. Connections differ in the way they transmit load in two different directions (up and down). The problem is also observed as one surface cannot transmit load to another surface between two movable elements. It is advisable that connections are free from load transmission.

The main load cases for which container strength should be characterized are: the compression with buckling, side and base bending and torsion, and force to unlatch the side.

\section{Design specifications of a foldable containers}

In the application, there are three types of design of plastic containers: rigid, foldable (Fig. 1) and nest design of container.

Specification of design parameters for containers includes the following: application type, standards and directives, ambient temperature, compatibility, material, colour, weight, dimensions, performance, load, logo, markings, resistance to chemical, thermal and UV effects. Dimensions of considered foldable containers for our research are given in Tab. 1.

Technical characteristics of the container are: pallet size that enable containers to be placed on $(800 \times 1200$ and $1000 \times 1200 \mathrm{~mm}$ ), material PP polypropylene (minimum modulus of elasticity of $1000 \mathrm{MPa}$ ), ambient temperature -30 to $+50{ }^{\circ} \mathrm{C}$, payload $15 \div 25 \mathrm{~kg}$, maximum deformation of the base $8 \div 10 \mathrm{~mm}$, maximum deformation of the longer side $10 \mathrm{~mm}$, payload for sides of erected container: $20 \times(15 \div 25)=300 \div 500 \mathrm{~kg}$, a safety factor of 3 , the ratio of the height of the erected to folded container 3 to 6 , the minimum / maximum material thickness $1,5 / 3 \mathrm{~mm}$, radius (minimum $0,5 \mathrm{~mm}$, maximum $2,5 \mathrm{~mm}$, special - on the edge of the base $6 \mathrm{~mm}$ ), the weight of container $0,5 \div 2 \mathrm{~kg}, 5$ years service interval, the number of opening-closing cycles up to 1000 etc.

Construction features: handles on the short side, stacking of folded and unfolded containers, washing and maintenance of containers, barcode, logo, markings, stacking compatibility with existing containers, colour, resistance to chemical, thermal and UV, etc.

Requirements for design typically are: minimum clearance between the flat surface of the side wall and the base, increased stiffness of side walls and the base, as well as columns. Transfer of the vertical load should be enabled via vertical edges of the sides to the base. Vertical columns should have a significant stiffness, and rigidity. 

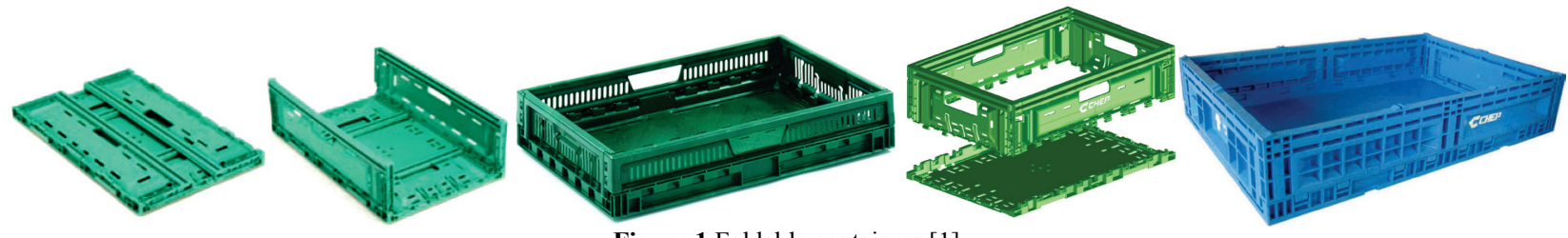

Figure 1 Foldable containers [1]

Table 1 External dimensions of the foldable container

\begin{tabular}{|c|c|c|c|}
\hline RK1 & $\begin{array}{c}\text { Shorter side }-A \\
/ \mathrm{mm}\end{array}$ & $\begin{array}{c}\text { Longer side }-B \\
/ \mathrm{mm}\end{array}$ & $\begin{array}{c}\text { Height } H(A / 2) \\
/ \mathrm{mm}\end{array}$ \\
\hline RK2 & 200 & 300 & 100 \\
\hline RK3 & 300 & 400 & 150 \\
\hline RK4 & 600 & 600 & 200 \\
\hline RK5 & 800 & 800 & 300 \\
\hline RK6 & 500 & 1200 & 400 \\
\hline
\end{tabular}

\section{Numerical FEM analysis of plastic foldable container}

FEM analysis is one of the most widely used engineering analysis techniques to solve different engineering problems $[2 \div 6]$. In this paper numerical analysis was conducted by the application of finite elements using "KOMIPS" software [7, 8].

\subsection{Buckling force of the long side}

Long side FE models include the bottom face simply supported (surface support) and load continually applied to each node of the top face pointing downwards (Fig. 2). Modulus of elasticity was $E=1200 \mathrm{MPa}$. Total compressive load pointing downwards, equally distributed along the side, was $4023 \mathrm{~N}(400 \mathrm{~kg})$. This equated to $1341 \mathrm{~kg}$ of linear force acting upon entire length of the top face of the crate.

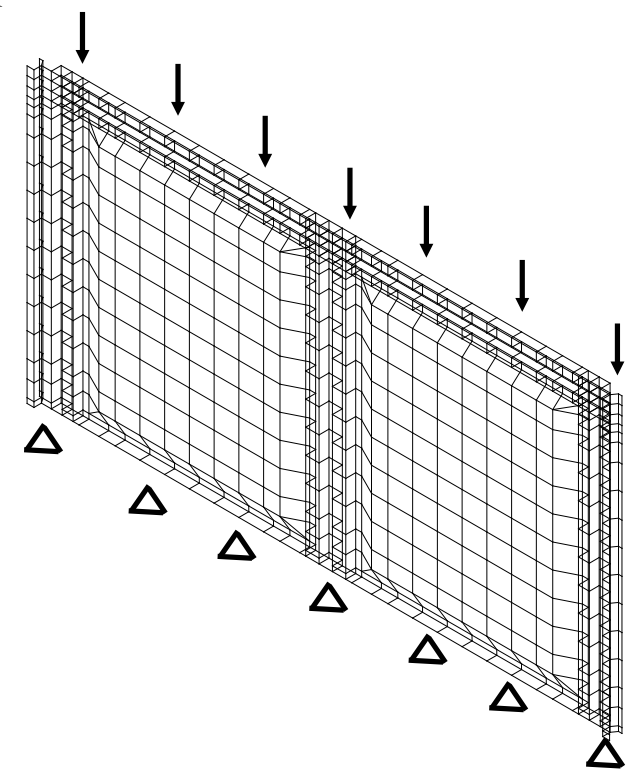

Figure 2 Numerical model

Long side compression strength is presented in Figs. 3 and 4.

The base of buckling analysis for the long side is calculated natural frequency and main mode oscillation. Natural frequencies and the modes shapes for the first three modes are shown in Fig. 5.

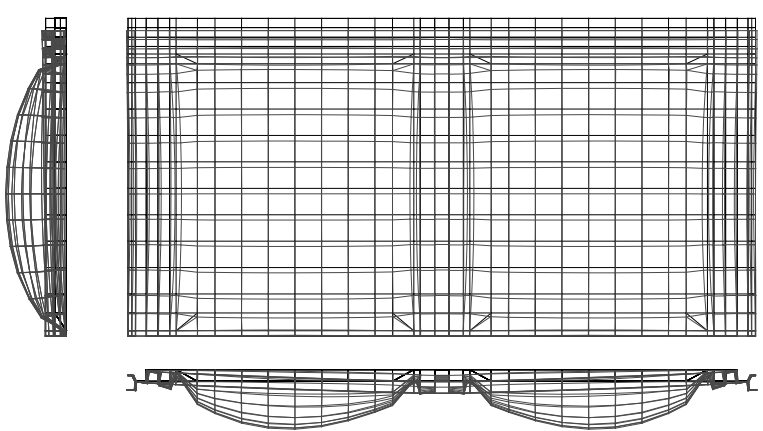

Maximum total spatial deformation was 3,7 mm, vertical deformation of top edge was $1 \mathrm{~mm}$, lateral deformation in horizontal plane of the top edge middle point was $0,92 \mathrm{~mm}$.

Figure 3 Deformation of long side
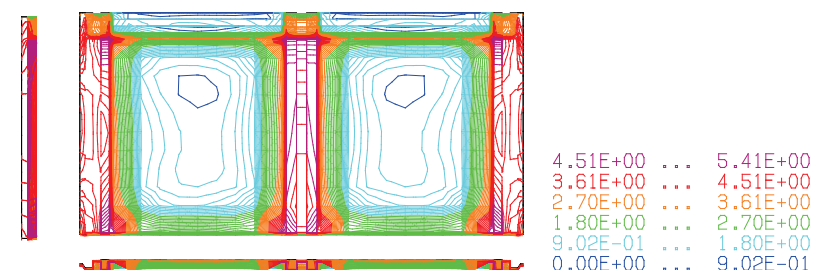

Von Mises stress/MPa (Max 5,41 MPa)

Figure 4 Stress field of long side

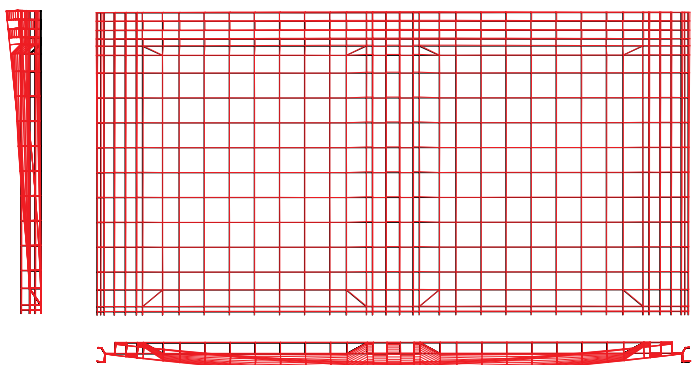

First mode. Natural frequency: $32,4 \mathrm{~Hz}$. Maximum horizontal lateral deformation of the top edge middle point is $3,3 \mathrm{~mm}$

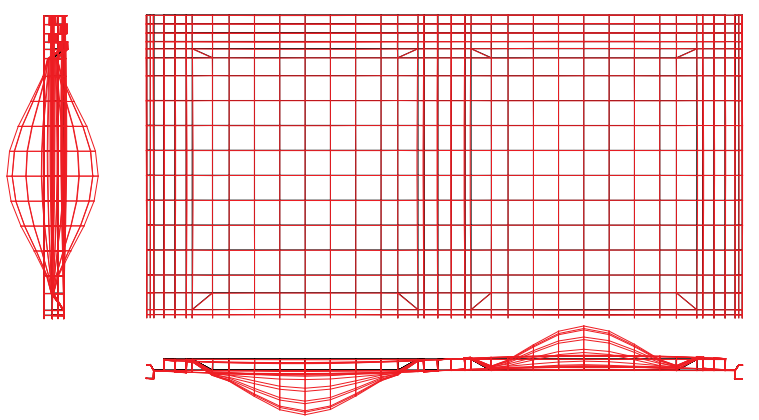

Second mode. Natural frequency: 61,7 Hz. Maximum horizontal lateral deformation of the top edge middle point is $6,3 \mathrm{~mm}$ 


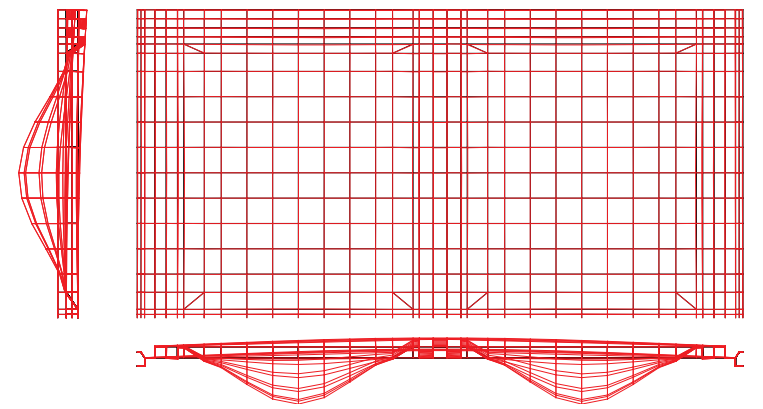

Third mode. Natural frequency; 65,9 Hz. Maximum horizontal lateral deformation of the top edge middle point is $6,5 \mathrm{~mm}$

Figure 5 First three modes oscillations

\subsection{Calculation of the base}

Further in this paper we shall demonstrate how dimensioning and analysis of container base behaviour is done for different types of containers. The bottom side of the base is populated with a grid of ribs. The footprint of the base is $600 \times 400 \mathrm{~mm}$. There was considered denser grid of the ribs. Fig. 6 shows results for one of the variants.
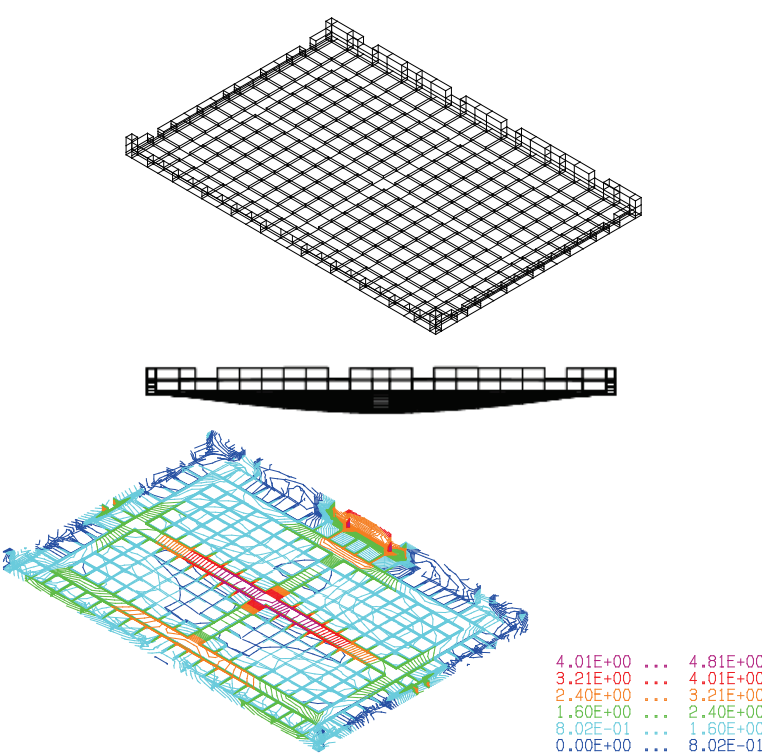

Figure 6 Base model, $25 \mathrm{~kg}$ load, deflection ( $\max 10,1 \mathrm{~mm})$, von Mises stress/MPa

Tabs. 2 and 3 show influence of the thickness of the base, the grid density and the ribs size on maximum deformation and stress of the base under continuous load of $25 \mathrm{~kg}$.

Table 2 The maximum deformation $/ \mathrm{mm}$ for $E=1200 \mathrm{MPa}$ at $20^{\circ} \mathrm{C}$.

\begin{tabular}{|l|c|}
\hline \multicolumn{1}{|c|}{ Model } & Deformation $/ \mathrm{mm}$ \\
\hline Full plate thickness 5 mm & 9,2 \\
\hline $\begin{array}{l}\text { Plate thickness } 1 \mathrm{~mm} \text {, ribs thickness } 4 \mathrm{~mm} \\
\text { and height } 4 \mathrm{~mm} \text {, raster } 10 \times 10 \mathrm{~mm}\end{array}$ & 4,8 \\
\hline $\begin{array}{l}\text { Plate thickness } 1 \mathrm{~mm} \text {, ribs thickness } 4 \mathrm{~mm} \\
\text { and height } 4 \mathrm{~mm}, \text { raster } 15 \times 13,33 \mathrm{~mm}\end{array}$ & 7,7 \\
\hline $\begin{array}{l}\text { Plate thickness } 1 \mathrm{~mm} \text {, ribs thickness } 4 \mathrm{~mm} \\
\text { and height } 4 \mathrm{~mm}, \text { raster } 20 \times 10 \mathrm{~mm}\end{array}$ & 8,3 \\
\hline $\begin{array}{l}\text { Plate thickness } 2 \mathrm{~mm}, \text { ribs thickness } 4 \mathrm{~mm} \\
\text { and height } 3 \mathrm{~mm}, \text { raster } 20 \times 20 \mathrm{~mm}\end{array}$ & 12 \\
\hline $\begin{array}{l}\text { Plate thickness } 1 \mathrm{~mm}, \text { ribs thickness } 4 \mathrm{~mm} \\
\text { and height } 4 \mathrm{~mm}, \text { raster } 20 \times 20 \mathrm{~mm}\end{array}$ & 13 \\
\hline
\end{tabular}

This type of the container base sets the demand for maximum deflection of $10 \mathrm{~mm}$.

Table 3 Rib: $t=4 \mathrm{~mm}$, raster $15 \times 15 \mathrm{~mm}, E=1200 \mathrm{MPa}$

\begin{tabular}{|c|c|c|}
\hline Rib height $/ \mathrm{mm}$ & Deformation $/ \mathrm{mm}$ & Stress/MPa \\
\hline 3 & 7,7 & 27,6 \\
\hline 4 & 6,76 & 23 \\
\hline 5 & 5,72 & 18,6 \\
\hline 6 & 5,7 & 17,6 \\
\hline 7 & 4,7 & 14,4 \\
\hline 8 & 4,3 & 13 \\
\hline 9 & 4 & 11,8 \\
\hline 10 & 3 & 9 \\
\hline
\end{tabular}

\subsection{Bending and torsion of the long side}

Calculation of bending due to the longer side of the vertical deformation of the upper edge of the page is shown in Fig. 7. We see that this deformation already comes to the yield point of the material.

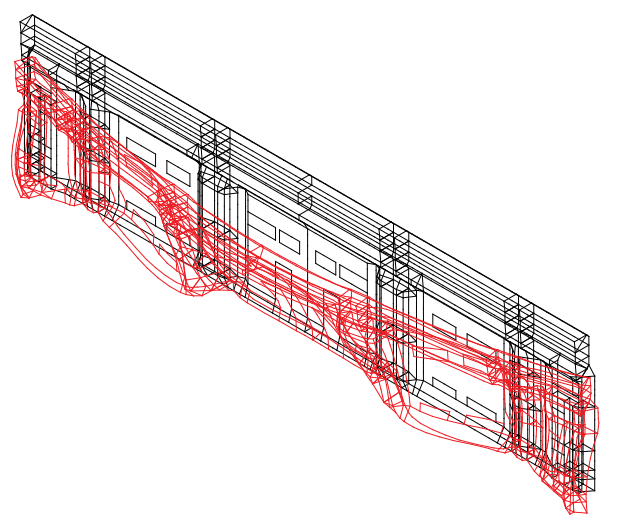

Deformation 1,53 $\mathrm{mm}$ (vertical $1 \mathrm{~mm}$, horisontal 1,3 mm)

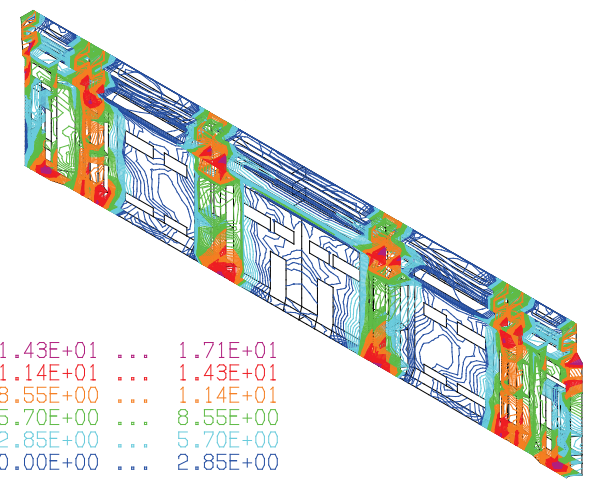

von Mises stress/MPa

Load: vertical deformation the upper edge for $1 \mathrm{~mm}$

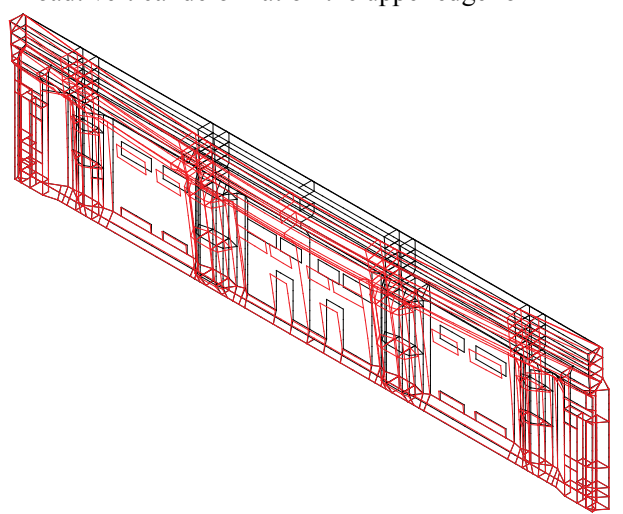

The first mode shape: fol $=67,9 \mathrm{~Hz}$ (horizontal amplitude $4 \mathrm{~mm}$ ) Figure 7 The calculation results of the longer side of one type of container company Tontarelli 
The sum of reaction forces of supports in the vertical direction equates to $6900 \mathrm{~N}$. This is equivalent to $1 \mathrm{~mm}$ of vertical deformation of the side's upper edge.

Let us introduce a ratio that is equivalent to reaching the limit of strength of materials under static load: $27 / 17,1$ $=1,58$. Another ratio - dynamic / static horizontal amplitude of the middle of the side top is: $4 / 1,3=3$. Since the ratio related to the yield point of the material is $3<1,58$ plastic deformation of the side will occur first, which is an unfavourable outcome. Estimated total force of plastic deformation of entire container is: $6900 \mathrm{~N} * 1,58 *(2+2$ $* 2 / 3)=14400 \mathrm{~N}$.

Fig. 8 shows calculation of twisting side under torque acting along its longitudinal axis.

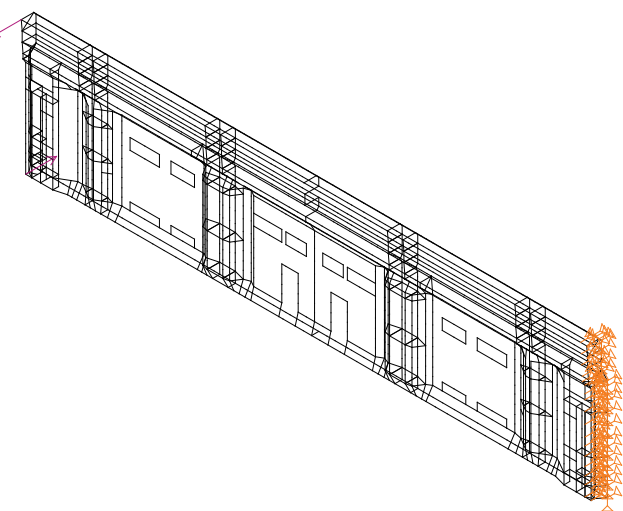

Model, torsion load $F=2 \times 10 \mathrm{~N}$

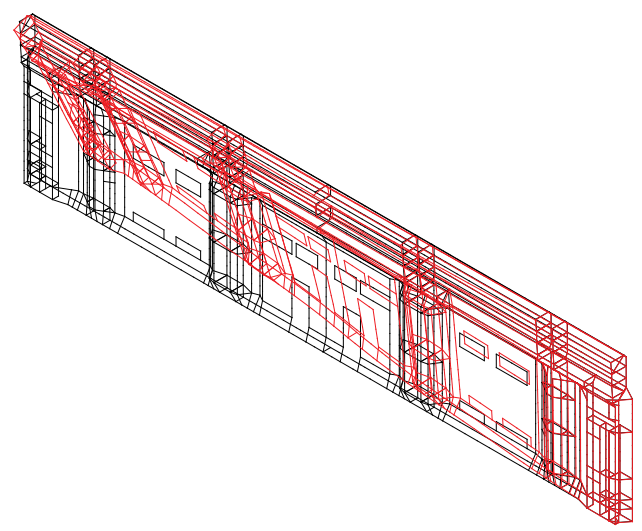

Maximal deformation $25,8 \mathrm{~mm}$

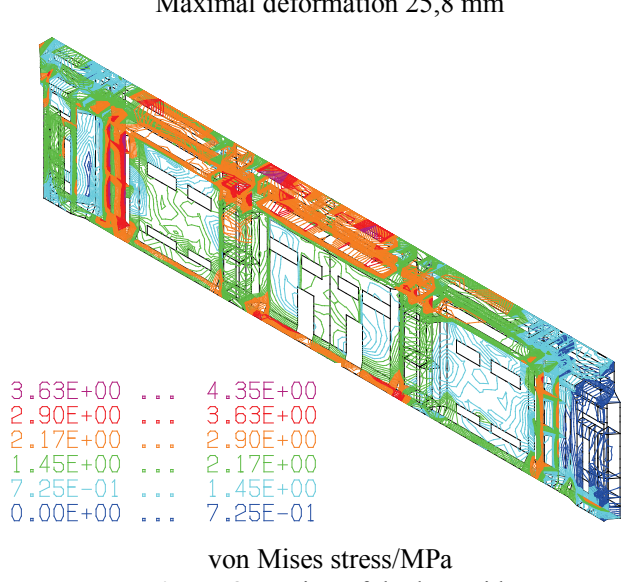

Figure 8 Torsion of the long side

It is obvious that large deformation and low stress is present.

\section{Experimental analysis of plastic foldable packaging}

Measurements in this research were carried out at the Laboratory for Structural Integrity at the Faculty of Mechanical Engineering in Belgrade. We used the data acquisition system that exists in the laboratory and the information from existing papers $[10,11]$

Experimental verification of the given numerical analysis was executed with the described equipment and software for 3D optical deformation measurements on the Instron testing machine, [9]. Results are shown in the following picture. The measured vertical deformation was 1,7 mm (Fig. 9) for the first example first measurement.

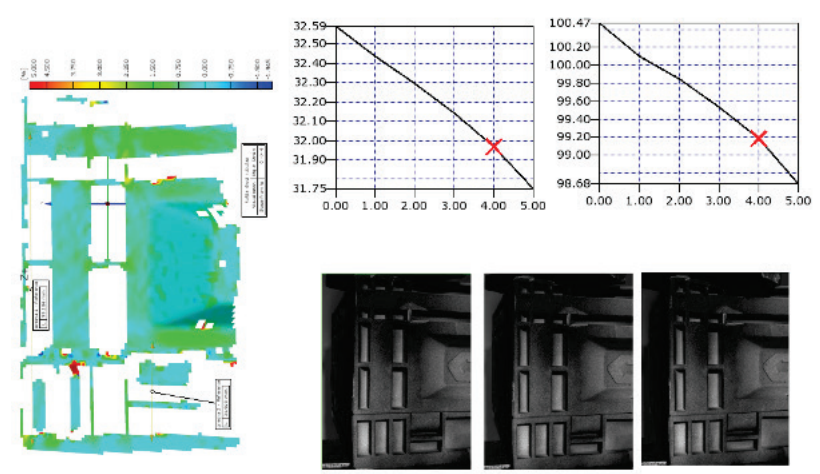

Figure 9 The example of measuring deformation

Next example is buckling effects which appeared much before the plastic deformation with experimental analysis (Figs. 10 and 11). Buckling was determined by the means of $3 \mathrm{D}$ optical measurement equipment.
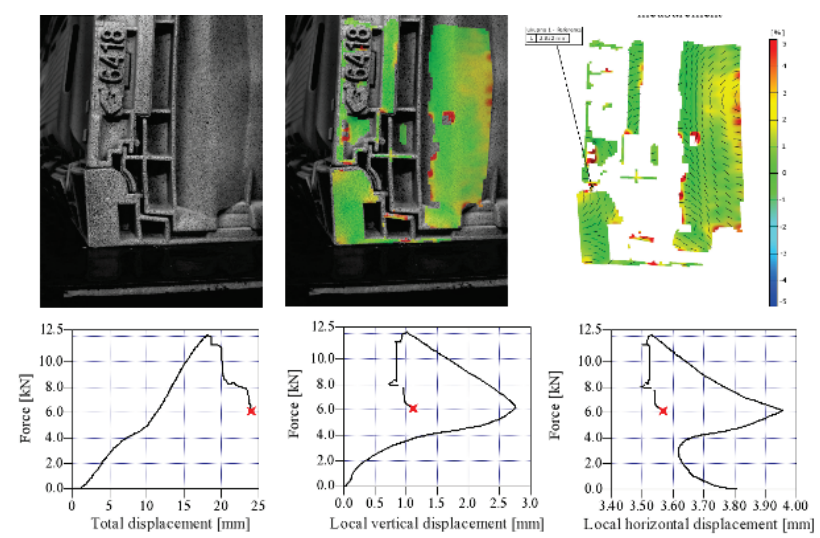

Figure 10 Experimental buckling analysis 1

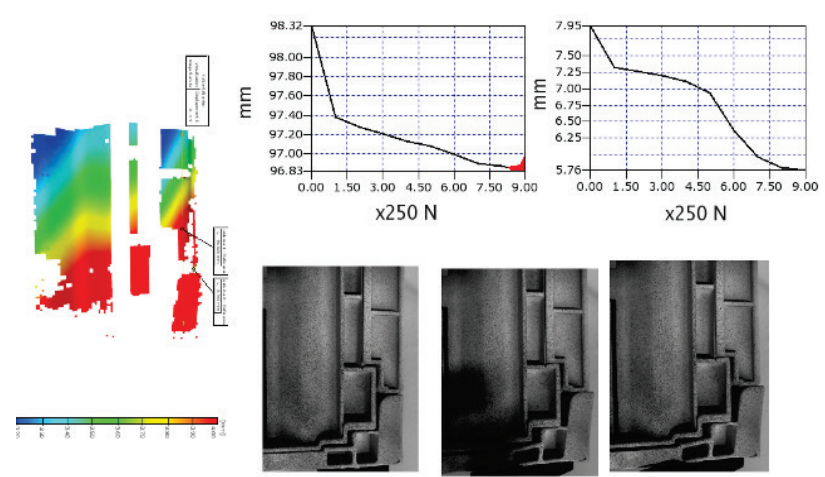

Figure 11 Experimental buckling analysis 2

The first deformation test of the base was executed by placing two loads $17 \mathrm{~kg}$ each which equated to total 
weight of $34 \mathrm{~kg}$. Loads were placed in the centre of the base. The measurement result is shown in Tab. 4 .

Table 4 Deformation of the base
\begin{tabular}{|c|l|c|}
\hline & Container & Def./mm \\
\hline 1 & 10934 - container on the 2 longer edge & 23 \\
\hline 2 & Arca Class-container on the 2 longer edge & 15 \\
\hline 3 & 6422 - only base on the 4 edge & 20 \\
\hline 4 & 10934 - container on the 4 edge & 18 \\
\hline 5 & Meat - container on the 4 edge & 15 \\
\hline 6 & Tontarelli old 110 - container on the 4 edge & 15 \\
\hline 7 & AU - container on the 4 edge & 8 \\
\hline
\end{tabular}

The results of the second deformation measurement due to the continuous base load are given in Fig. 12 and in the Tab. 5 .
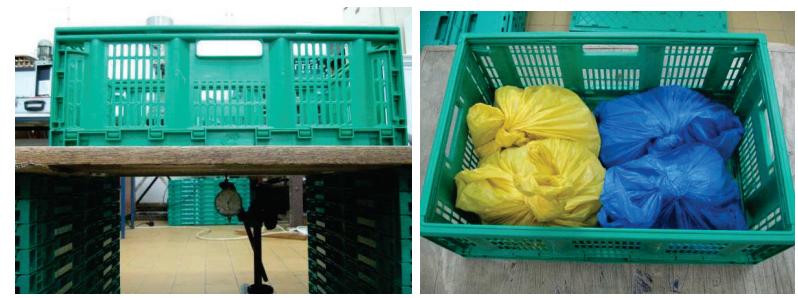

Figure 12 Measuring deformation of the base

Table 5 Deformation of the base at time

\begin{tabular}{|c|c|c|c|c|}
\hline & \multicolumn{4}{|c|}{ Time } \\
\hline Deformation base/mm & $0 \mathrm{~min}$ & $10 \mathrm{~min}$ & $12 \mathrm{~h}$ & $24 \mathrm{~h}$ \\
\hline Sample 1 & 10 & 11,1 & 13,1 & 14,6 \\
\hline Sample 2 & 10,1 & 11,6 & 13,5 & 15,75 \\
\hline Sample 3 specimen 1 & 9,5 & 10,55 & 13,15 & - \\
\hline Sample 3 specimen 2 & 9,5 & 10,5 & 13,1 & - \\
\hline
\end{tabular}

The next test we performed was about vertical pressure combined with a twist of the container. The objective of this test was to obtain an answer to the following fundamental questions: what is the force required to initiate plastic deformation and buckling, and which comes first. Optimal design of a container can be achieved if we can ensure that plastic deformation occurs first. This test was performed on Instron test machine using the conventional and 3D optical measurement force and deformation.

From first method we obtained a force-displacement diagram for the entire container. From second method yielded 3D deformation field for the container.

Fig. 13 provides an overview of the equipment that was used to perform all of the pressure tests on containers.

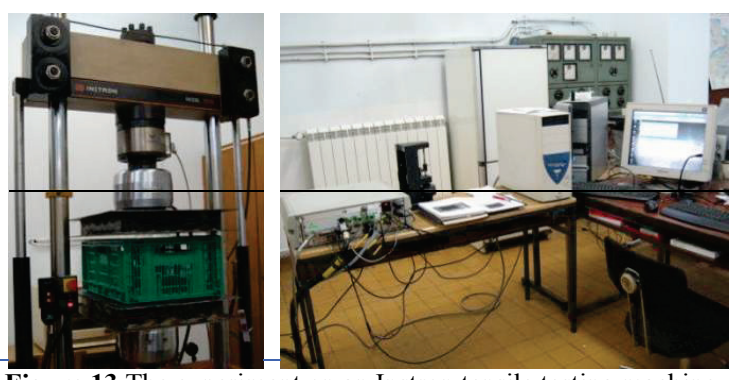

Figure 13 The experiment on an Instron tensile testing machine

For this test we took the same container type with the following dimensions: $600 \times 400 \times 189 \mathrm{~mm}$. Two groups of five containers were tested. Each group passed four tests:

- $\quad$ the first group of containers $2,4,3$, containers $1+3$

- $\quad$ the second group of containers $1,2,3$, container $4+5$.

Fig. 14 shows each test set up and the results of each individual test.

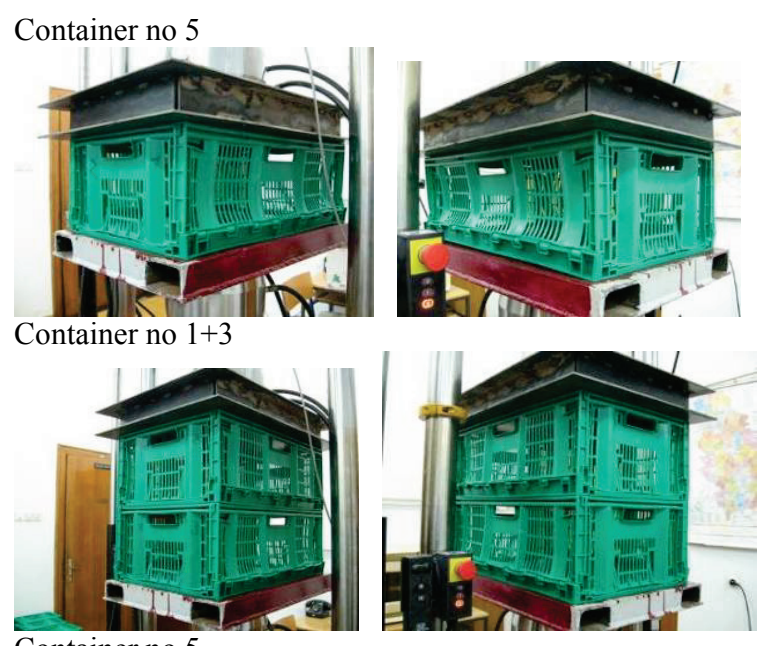

Container no 5

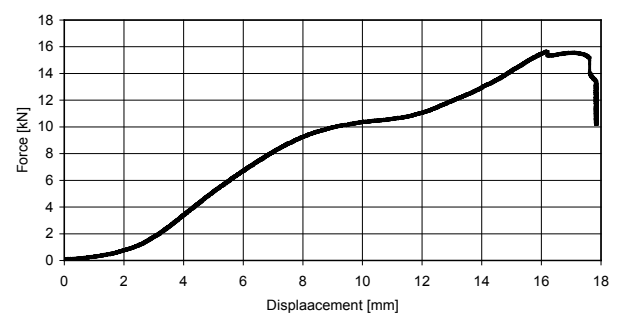

Comment: buckling occurs at about $10,2 \mathrm{kN}$ Container no $1+3$

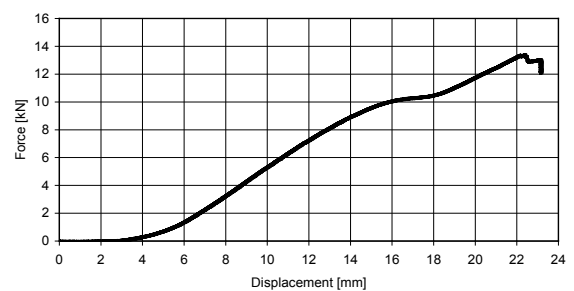

Comment: buckling occurs at about $10,4 \mathrm{kN}$

Figure 14 Images of measurements and measurement results

Analysis of measurement results led to our conclusion:

- Relationship between the force and the deformation is non-linear,

- Non-linearity of the specified function stems from the existence of the gap between the sides and the base, and change of the load transfer path,

- Buckling of the container began to occur much before the plastic deformation occurred and the load carrying capacity of the container was reduced by almost $50 \%$.

On the basis of this study we conclude that this type of container had an unfavourable behaviour.

Relationship between force and deformation is almost linear (Fig. 15). That means here appropriate resistance against buckling is achieved. 


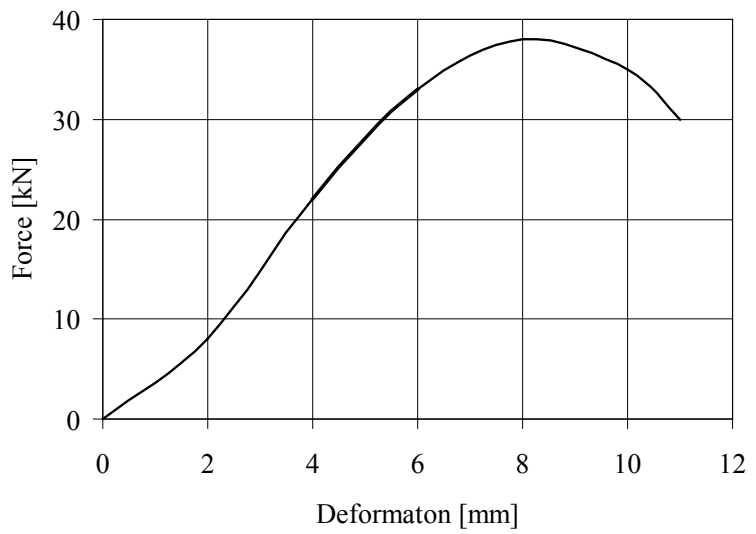

Figure 15 Function force-deformation

This container has favourable behaviour.

\section{Conclusion}

The methodology described here showed satisfying results regarding the buckling effects on plastic packaging. We gained conclusions about the root-causes of the buckling. The analysis was consistent with all previously conducted observations of container behaviour due to compressive loads. The difference is that the previous conventional observations of deformations could only detect the consequence of buckling (structural failure) where the $3 \mathrm{D}$ optical equipment enabled us to also understand the root-cause.

This type of analysis is applicable to a wide range of structural problems with diverse loading patterns.

Experimental and numerical analyses have shown high degree of correlation.

\section{Acknowledgements}

Authors acknowledge support from Serbian Ministry of Education and Science, projects number TR35040.

\section{References}

[1] http://www.chep.com/rpcs/crates/

[2] Arashmehr, J.; Rahimi, G. H.; Rasouli, S. F. An Experimental and Numerical Investigation of a Grid Composite Cylindrical Shell Subjected to Transverse Loading. // Strojniški vestnik - Journal of Mechanical Engineering. 59, 12(2013), pp. 755-762. DOI: 10.5545/svjme.2013.1106

[3] Dezelak, M.; Stepisnik, A.; Pahole, I.; Ficko, M. Evaluation of Twist Springback Prediction after an AHSS Forming Process. // International Journal of Simulation Modelling. 13, 2(2014), pp. 171-182. DOI: 10.2507/IJSIMM13(2)4.261

[4] Aghdam, N. J.; Hassanifard, S.; Ettefagh, M. M.; Nanvayesavojblaghi, A. Investigating Fatigue Life Effects on the Vibration Properties in Friction Stir Spot Welding Using Experimental and Finite Element Modal Analysis. // Strojniški vestnik - Journal of Mechanical Engineering. 60, 11(2014), pp. 735-741. DOI: 10.5545/sv-jme.2013.1324

[5] Yuan, J. Numerical calculation and experimental research on sound loudness in sound field of structural-acoustic coupling cavity. // Tehnicki vjesnik-Technical Gazette. 21, 6(2014), pp. 1361-1369.

[6] Toma, M.; Njilie, F. E. A.; Ghajari, M.; Galvanetto, U. Assessing motorcycle crash-related head injuries using finite element simulations. // International Journal of
Simulation Modelling. 9, 3(2010), pp. 143-151. DOI: 10.2507/IJSIMM09(3)3.164

[7] Maneski, T. Computer modeling and structure, Monography, Faculty of Mechanical Engineering, Belgrade, 1998

[8] Software KOMIPS, Faculty of Mechanical Engineering

[9] Software ARAMIS, GOM, Germany

[10] Celovic, S.; Maneski T.; Vuherer T.; Tipsarević M.; Zrilić M. Experimental and Numerical Analysis of Foldable Plastic Packaging Buckling Failure // ICMEM, Prešov, Slovakia, 2012

[11] Gubeljak, N.; Chapetti, M. D.; Predan, J.; Landes, J. D. CTOD-R curve construction from surface displacement measurements. // Engineering fracture mechanics. 8, 11(2011), pp. 2286-2297. DOI: 10.1016/j.engfracmech.2011.05.002

Authors' addresses

Sevket Čelović, MSc in Mech Eng

Volkswagen

P.O. Box 1849, D-38436 Wolfsburg

Germany

E-mail: investor.relations@volkswagen.de

Miloš Tipsarević, MSc in Advanced Mech Eng

Danfoss Business System

4401 N. Bell School Road

Loves Park, Illinois 61111, Denmark

E-mail: mfbg@yahoo.co.uk

Taško Maneski, Professor

Faculty of Mechanical Engineering, University of Belgrade Kraljice Marije 16, 11000 Belgrade, Serbia

E-mail: tmaneski@mas.bg.ac.rs

Tomaž Vuherer, Assist. Professor

Strojniška fakulteta

Univerza v Mariboru

Smetanova 17, SI-2000 Maribor, Slovenia

E-amil: vuhi38@yahoo.com

Dražan Kozak, Professor

Strojarski fakultet u Slavonskom Brodu

Sveučilište J. J. Strossmayera u Osijeku

Trg I. B. Mažuranić 2, HR-35000 Slavonski Brod, Croatia

E-mail: dkozak@sfsb.hr 